\title{
PENGARUH KUALITAS LAYANAN TERHADAP KEPUASAN DAN WORD OF MOUTH PADA HOSPITAL NASIONAL GUIDO VALADARES DILI TIMOR LESTE
}

\author{
Roslina Lali Wuda ${ }^{1}$ \\ Ni Wayan Sri Suprapti \\ 1,2 Fakultas Ekonomi dan Bisnis Universitas Udayana, Bali, Indonesia \\ Email: roslinamoto@yahoo.com
}

\begin{abstract}
ABSTRAK
Tujuan dari penelitian ini adalah untuk mengetahui pengaruh dari kualitas layanan terhadap kepuasan dan komunikasi Word Of Mouth (WOM) pada pasien rawat inap di Hospital Nasional Guido Valadares Dili Timor Leste. Pengujian hipotesis menggunakan analisis Path. Populasi dalam penelitian ini adalah semua pasien yang sudah pernah mengalami rawat inap di Hospital Nasional Guido Valadres Dili Timor Leste, metode penelitian sampel di lakukan dengan metode purposive sampling dengan jumlah responden sebanyak 150 responden. Pengujian hipotesis menggunakan analisis Path. Dalam penelitian ini dapat diambil sebuah kesimpulan bahwa : 1) kualitas layanan berpengaruh positif dan signifikan terhadap kepuasan, 2) kualitas layanan berpengaruh positif dan signifikan terhadap word of mouth, 3) kepuasan berpengaruh positif dan signifikan terhdap Word Of Mouth. 4) pasien yang dirawat pada Hospital Nasional Guido Valadares Implikasi praktis dari penelitian ini adalah sebagai informasi bagi management Hospital Nasional Guido Valadares Dili-Timor Leste.

Kata kunci : kualitas layanan, kepuasan, WOM.
\end{abstract}

\begin{abstract}
This research aims to study the effect of service quality onssatisfaction and word of mouth of hospitalized patients of Hospilized Guido Valadares in Dili Timor Leste. The population of this study is all patiens who had undargone in patient at hospitalized Guido Valadares in Dili Timor Leste. The method of collecting data was porposive sampling. The number of respondents were 150 respondents. The data was analized by using path analisis. The population of this study is all patiens who had undargone in patient at hospitalized Guido Valadares in Dili Timor Leste. The method of collecting data was porposive sampling. The number of respondents were 150 respondents. The data was analized by using path analisis. The resultsof this study reveal that 1) Quality of service has positive and significant impact on satisfaction. 2) Quality of service has positive and significant impact on WOM. 3) satisfaction has positive and significant impact on WOM.
\end{abstract}

Keywods : Service Quality, Satisfaction, WOM.

\section{PENDAHULUAN}


Pada umumnya pendidikan masyarakat yang semakin meningkat menyebabkan makin meningkatnya pula upaya untuk memperbaiki kualitas kehidupan yang semakin hari semakin berubah. Salah satu indikator kualitas kehidupan adalah makin baiknya tingkat kesehatan masyarakat. Tingkat pendidikan yang semakin meningkat dapat disertai dengan meningkatnya daya beli yang semakin meningkat pula serta menyebabkan masyarakat semakin peduli atau semakin sadar akan kesehatan mereka atau semakin sadar akan kesehatan diri dan lingkungan.

Setiap orang mempunyai kebutuhan yang muncul akibat semakin meningkatnya tingkat kesadaran masyarakat, seperti misalnya kebutuhan atau permintaan terhadap jasa layanan rumah sakit, jasa dokter prakter, produk obatobatan dan layanan apotik serta produk dan jasa penunjang lainnya. Kalau dilihat dari sisi bisnis bahwa kondisi tersebut tentunya merupakan bidang usaha yang cukup prospektif sehingga banyak menarik minat para investor untuk mendirikan usaha yang berkaitan dengan permintaan masyaraakat tersebut

\section{Kualitas Layanan ( Service Quality )}

Kualitas layanan merupakan yang sangat penting bagi setiap perusahaan apapun bentuk produk yang dihasilkan. Tjiptono (2008:85) menyatakan secara sederhana kualitas layanan diartikan sebagai ukuran seberapa bagus tingkat layanan diberikan mampu sesuai dengan eskpektasi pelanggan. Apabila perceived service sesuai dengan expected service, maka kualitas layanan dipersiapkan sebagai kualitas ideal. Sebaiknya apabila perceived service lebih jelek dibandingkan expected service, maka kualitas layanan dipersepsikan negative atau buruk. Oleh sebab itu baik atau tidaknya kualitas layanan bergantung pada kemampuan 
perusahaan dan karyawannya memenuhi harapan pelanggan secara konsisten. Untuk mewujudkan layanan prima memerlukan pemahaman koprehensif menyangkut demensi kualitas layanan, factor-faktor penyebab buruknya kualitas layanan, dan strategi menyempurnakan kualitas layanan berkesinambungan (Tjiptono, 2008:93),

Pembahasan tentang konsep kualitas layanan tentunya tidak dapat dipisahkan dengan istilah kualitas itu sendiri. Gronroos dalam Edi Rusandi (2004:11 dan 19) bahwa kualitas adalah apa yang konsumen katakan. Dalam hal ini mengandung makna bahwa kualitas hendaknya dilihat dari sudut pandang konsumen, konsumenlah menentukan nilai kualitas

Berdasarkan model kualitas layanan tersebut, Parasuraman (1988) menyatakan kualitas layanan ditentukan dalam lima dimensi penentu anatara lain tangibles, reliability, responsiviness, assurance dan empathy. Suprianto dan Ernawati (2010:214) mendeskripsikan kelima dimensi SERVQUAL dalam layanan rumah sakit sebagai berikut :

Bukti fisik (tangibles) adalah tampilan fasilitas fisik, peralatan, personil dan bahan komunikasi yang menunjang jasa rumah sakit yang ditawarkan.

Kendalan (reliability) berarti produk dan jasa yang disampaikan sesuai dengan janji yang pernah diberikan kepada pasien dapat diandalkan,dipercaya dan dipertanggungjawabkan, contohnya jam buka pelayanan yang tertera dipapan dan dokter tetapkan waktu sesuai dengan yang dijanjikan.

Daya tanggap ( responsiviness ) adalah kemauan untuk menyediakan pelayanan dengan cepat dan mau membantu pasien dengan indicator sebagai baerikut : 
Waktu tunggu di loket serta waktu tunggu untuk mendapatkan pelayanan medis, apotik dan labaratorium,Kecepatan datang bila dibutuhkan.

Jaminan (assurance) pada saat menyampaikan produk atau jasa disertai rasa hormat dan sopan. Proses penyampaian dapat pula menimbulkan rasa percaya dan yakin akan jaminan sembuh. Indikatornya adalah imformasi tentang penyakit, dan prognocis penyakit.

Empati (empathy) berarti memberikan jasa untuk mendengarkan adanya perhatian akan keluhan, kebutuhan keinginan dan harapan pasien..

Tjiptono (2008:125) menyatakan sampai saat ini model SERVQUAL dipersepsikan layanan. Model tersebut sudah diterapkan dalam berbagai macan jenis usaha seperti misalnya,dalam bidang kesehatan, pariwisata, reparasi, bank dan intansi pemerintah.

\section{Kepuasan Pelanggan (Customer Satisfaction)}

Kepuasan pelanggan merupakan salah satu kunci keberhasilan perusahaan. Pelanggan yang puas akan cenderung loyal dan menyampaikan WOM positif terhadap sebuah merek atau perusahaan. Perusahaan dapat meningkatkan keuntungan jangka panjang apabila berhasil memuaskan pelanggan. Kotler dan Keller (2009:177) menyatakan kepuasan adalah perasaan senang atau kecewa sesorang yang muncul setelah membandingkan kinerja produk yang dipikirkan terhadap kinerja yang diharapkan. Apabila kinerja barada dibawah harapan, pelanggan tidak puas. Jika kinerja memenuhi harapan, pelanggan puas. Jika kinerja melebihi harapan,pelanggan amat puas atau senang. Pembeli membentuk harapan mereka dengan memperhatikan pengalaman pembelian mereka sebelumnya, 
nasihat teman dan kolega, dan janji serta informasi para pemasar dan persaingnya. Jika pemasar memberikan harapan terlalu tinggi, para pembeli cenderung akan kecewa. Sebaliknya, jika perusahaan menetapkan harapan terlalu rendah, maka para pembeli tak akan tertarik, meskipun apabila mereka benar-benar membeli akan merasa puas.

Menurut Tjiptono (2008:169) kepuasan pelanggan juga berpotensi memberikan sejumlah manfaat spesifik diantaranya:

Berdampak positif terhadap loyalitas pelanggan, berpotensi menjadi sumber pendapatan masa depan terutama melalui pembelian ulang.

Menekan biaya transaksi pelanggan di masa depan terutama biaya-biaya komunikasi pemasaran, penjualan, dan layanan palanggan.

Menekan volatilias dan resiko berkenaan dengan prediksi aliran kas masa depan. Meningkatkan toleransi harga, terutama kesedihan palanggan untuk membayar harga premium dan pelanggan cenderung tidak muda tergoda untuk beralih pemasok.

Menumbuhkan rekomendasi getok tular positif.

Pelanggan cenderung lebih reseptif terhadap product-line extention, brand extention, dan new-add-on service yang ditawarkan perusahaan.

Supriyanto dan Ernawaty (2010:310) menyatakan kepuasan pasien adalah suatu keadaan ketika kebutuhan, keinginan, dan harapan pasien dapat dipenuhi melalui produk atau jasa yang dikonsumsi. Oleh karena itu kepuasan pasien adalah rasio kualitas yang dirasakan oleh pasien dibagi dengan kebutuhan, keiginan, dan harapan pasien. Harapan adalah keinginan yang bersifat individu dan 
spesifik. Harapan sangat dipengaruhi oleh pengalaman dan selera. Pemahaman akan harapan adalah prasyarat untuk meningkatkan kualitas dan mencapai kepuasan pelanggan. .

\section{Komunikasi WOM}

Komunikasi WOM sangat penting bagi pemasar didasarkan pada keyakinan bahwa pelanggan yang puas adalah tenaga penjual yang paling baik. Pelanggan yang merasa puas akan menyampaikan hal itu kepada keluarga, teman atau tetangga, sedangkan pelanggan yang tidak merasa puas akan merupakan penghalang bagi penjualan. Sweeney (2008) menyatakan WOM semakin dikenal sebagai bentuk promosi yang sangat penting, khususnya dalam lingkungan industry jasa, dimana kualitas mempunyai peranan yang penting sebagai acuhan bagi pelanggan dalam mengambil keputusan. Asseal (2004 : 464) mendesrkipdikan WOM adalah komunikasi pribadi antara dua individu atau lebih, misalnya antar pelanggan atau antar anggota dari satu kelompok.

Menurut TJiptono (2008:90)) bersifat kredibel dan efektif selalu disampaikannya lewat orang-orang yang dapat dipercayai pelanggan, seperti para ahli, teman, tetangga, keluarga, rekan kerja dan publisitas media massa. Disamping itu WOM juga cepat diterima sebagai reverensi, kerena pelanggan biasanya sulit mengevaluasi produk atau jasa yang belum dibelinya atau belum dirasakannya sendiri.

Suprapti (2010:248) menyatakan bila pemasar ingin meningkatkan komunikasi getok tular atau WOM yang positif tentang produknya, mereka harus paham tentang : 
Jenis komunikasi getuk tular yang trediri atas tiga jenis yaitu berita atau imformasi tentang produk, pemberian nasehat yang melibatkan ekspresi opini tentang produk itu dan pengalaman pribadi yang berkaitan dengan komentar tentang kinerja produk tersebut atau tentang alasan seseorang membelinya.

Proses komunikasi getok tular yaitu komuniksi yang mengalir dari para pemimpin opini kepada pengikutnya. Hal yang paling penting dari aliran komunikasi ini adalah apakah imformasi yang disampaikan bersifat negatif atau positif.

Kondisi untuk komunikasi getok tular yang merupakan factor dominan dalam setiap situasi. Komunikasi getok tular tidak lagi menjadi penting apabila konsumen telah memiliki kesan yang kuat terhadap suatu produk atau produk itu telah memiliki imformasi yang negatif.

Komunikasi WOM tidak selalu bersifat positif, tetapi bagi pelanggan yang merasa kecewa cenrung akan menyampaikan WOM negatif. Assail (2004:468) menyatakan komunikasi WOM negative mempunyai pengaruh yang lebih besar dari pada WOM positif. Apabila pelanggan kecewa, mereka akan tiga kali lebih sering menceritakan pengalaman yang tidak menyenangkan tersebut kepada kenalannya jika dibandingkan dengan pelanggan yang merasa puas.

\section{Kerangka Konseptual}

Olorunniwo (2006) menemukan bahwa selain service quality mempunyai pengaruh langsung terhadap behavioral intentions, service quality juga berpengaruh terhadap favorable behavioral intentions dengan dimediasi oleh customer satisfaction. Wahyuningsih dan Nurdin (2009) menyatakan behavioral intentions bias dalam bentuk keinginan untuk melakukan pembelian ulang atau 
keinginan untuk melakukan pembelian ulang atau keinginan untuk melakukan getok tular WOM.

Sesuai dengan tujuan penelitian, jumlah variable yang teridentifikasi, maka dapat dibangun suatu konsep model hubungan antara kualitas layanan dengan kepuasan WOM. Gambar 3.1 menunjukan kualitas layanan dibentuk oleh lima dimensi yaitu : Keandalan (Reliability), Daya Tanggap (Responsiveness), Jaminan (Assurance), Empaty (Empati), Bukti Fisik (Tangibles).

Persepsi pasien terhadap kelima demensi tersebut akan mempengaruhi tingkat kepuasannya dan komunikasi WOM dari pasien kepada keluarga, teman, tetangga atau kerabat lainnya.

Berdasarkan uraian karangka berpikir tersebut, maka dapat digambarkan hubungan antara kualitas layanan yang dapat meningkatkan kepuasan dan WOM

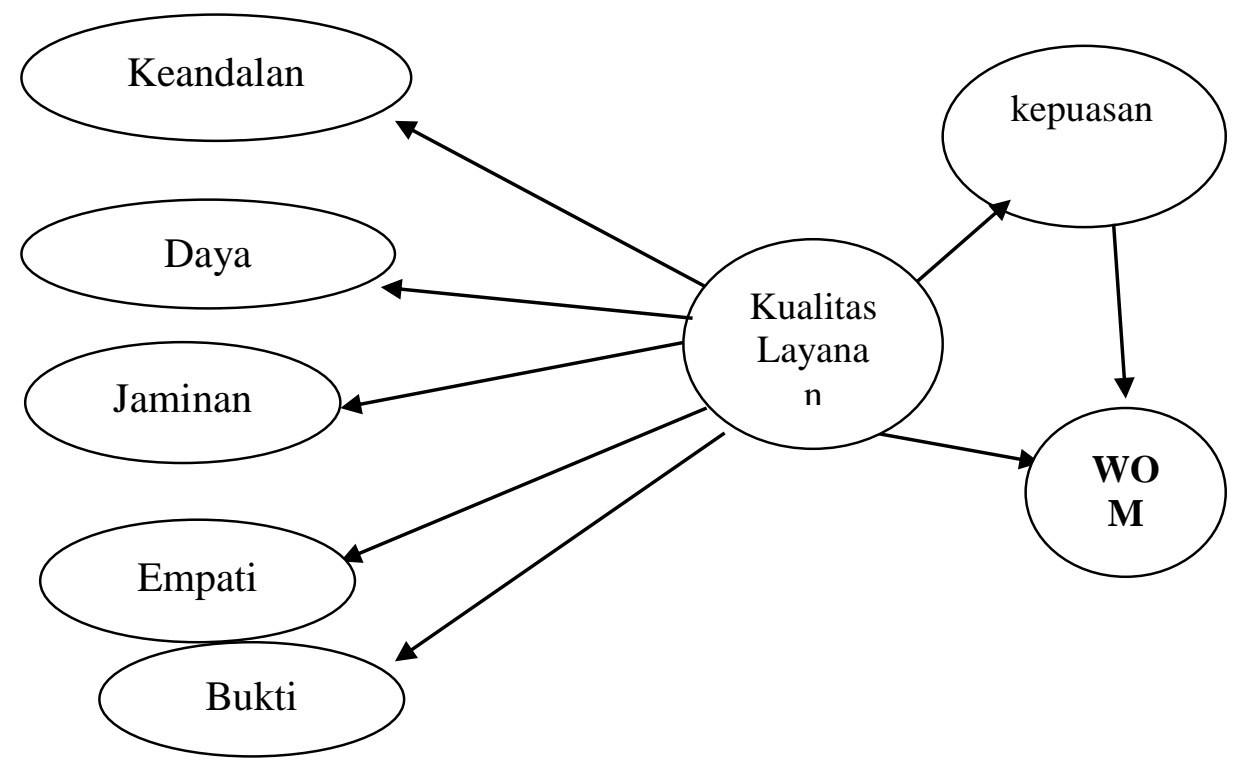

Gambar 1 Kerangka Konseptual Penelitian

Hipotesis Penelitian 
Berdasarkan kerangkah pemikiran dan modal konseptual yang telah dipaparkan maka dirumuskan hipotesis penelitian sebagai berikut :

1.Pengaruh kualitas layanan terhadap kepuasan

Olorunniwo (2006) menyatakan dimensi kualitas layanan mempunyai pengaruh positif terhadap kepuasan pelalanggan. Utama. Shabbier (2010) menemukan kualitas layanan yang diberikan oleh rumah sakit mempunyai pengaruh positif terhadap kepuasan pasien. Berdasarkan hasil penelitian tersebut maka diajukan hipotesis penelitian :

H1 : Kualitas layanan memeiliki berpengaruh positif dan signifikan terhadap kepuasan.

2. Pengaruh kualitas layanan dengan WOM

Zeithmal (1996) menyatakan pelanggan yang puas dengan layanan yang diterima akan menyebarkan WOM positif. Praswati (2009) menemukan kualitas layanan berpengaruh positif terhadap komunikasi WOM. . Sutomo (2009) menemukan kualitas layanan mempunyai pengaruh positif dan signifikan terhadap minat mereverensikan jasa rumah sakit. Semakin tinggi kualitas layanan, maka kepuasan pelaggan semakin tinggi dan menyebabkan minat mereverensikan jasa rumah sakit yang semakin tinggi. Berdasarkan hasil penelitian tersebut maka hipotesis yang diajukan :

H2 : Kualitas layanan berpengaruh positif dan signifikan terhadap WOM Pengaruh kepuasan dengan WOM

Lioyd dan Luk menyatakan pelanggan yang merasa nyaman dengan layanan akan berdampak positif terhadap kepuasan pelanggan, dan ini akhirnya mengarah pada WOM positif. Brown (2005) menyatakan ketika seorang pemasar mampu menawarkan tingkat kepuasan yang maksimal kepada konsumen, maka konsumen akan memiliki kecendrungan untuk melakukan WOM positif. Praswati (2009) menemukan kepuasan pelanggan berpengaruh positif terhadap kepuasan WOM. Zeithmal (1996) menyatakan pelanggan yang puas dengan layanan yang diterima akan menyebarkan WOM positif. Lovelock dan wirtz 
(2007:172) menyatakan beberapa penelitian telah menunjukan isi dari WOM yang dikomunikasikan oleh pelanggan dipengaruhi oleh tingkat kepuasannya. Chaniotakis dan Lymperepoulos (2009) menemukan

3.Kepuasan secara langsung mempengaruhi WOM pada tingkat kesehatan. Berdasarkan atas hasil penelitian tersebut maka hipotesis yang dapat diajukan:

H3 : Kepuasan berpengaruh positif dan signifikan terhadap WOM :

Tujuan dalam penelitian ini untuk menjelaskan pengaruh kualitas layanan terhadap kepuasan pada pasien rawatap di Hospital Nasional Guido Valadares.

Dan untuk menjelaskan pengaruh kualitas layanan terhadap WOM Pada pasien rawat inap di Hospital Nasional Guido Valadares.

Serta untuk menjelaskan kepuasan terhadap WOM pada pasien rawat inap di Hospital Nasional Giudo Valadares.

\section{METODE PENELITIAN}

Rancangan dan Ruang Lingkup Penelitian

Penelitian ini adalah penelitian yang deskriptif dan asosiatif yang merupakan salah satu jenis riset konklusif. Penelitian diskriptif ditandai dengan pernyataan yang jelas mengenai masalah penelitian yang spesifik dan rincian imformasi yang diperlukan. Malhotra (2009:93). Setiap variabel penelitian dideskripsikan secara rinci berdasarkan data yang diperoleh dari responden melalui metode survei dan kemudian dibahas hubungan antar variabel.

Lokasi dan subjek penelitian

Penelitian ini dilakukan di Hospital Nasional Guido Valadares Dili Timor Leste yang beralamat di jalan Bidau Santana

Kuesioner diberikan kepada pasien rawat inap pada Hospital Nasional Guido Valadares. Varibel pnelitian disusun berdasarkan permasalahan, tujuan penelitian, landasan teori, dan hasil penelitian sebelumnya. 
Ada tiga variabel laten yang dibahas dalam penelitian ini yaitu : kualitas layanan sebagai variabel bebas, variabel WOM sebagai variabel terikat, dan kepuasan pasien sebagai variabel mediasi.

Definisi Operasional variabel Penelitian

Kualitas Layanan adalah tingkatan kualitas layanan yang diberikan oleh petugas rumah sakit Nasional Guido Valadares kepada pasein rawat inap. Kualitas layanan ini terdiri atas lima dimensi (Parasuraman ; 1998 ) sebagai berikut :

(1) Keandalan (Reliability) adalah kemampuan pegawai Hospital Nasional Giudo Valadares untuk melaksanakan layanan yang dijanjikan secara meyakinkan dan akurat

(2) Daya Tanggap (reposiveness) adalah kesediaan petugas rumah sakit untuk membantu pasien dan memberikan layanan dengan cepat

(3). Jaminan (Assurance) adalah pengetahuan dan kesopanan pengawai rumah sakit yang dapat menimbulkan kepercayaan dan keyakinan dari pasien terhadap rumah sakit

(4). Empati (Empathy) adalah kesediaan pegawai Rumah Sakit untuk memberikan perhatian yang mendalam dan khusus kepada masing-masing pasien.

(5) Bukti Fisik (Tangibles) adalah pemampilan fasilitas fisik seperti fisik, kelengkapan fasilitas, kebersihan ruangan, dan penampilan petugas rumah sakityang dapat dilihat langsung oleh pasien

Kepuasan Pasien merupakan tingkat perasaan senang atau rasa kecewa pasien setelah menjalani pengobatan di Hospital Guido Valadares

WOM merupakan kesediaan pasien untuk merekomendasikan kepada keluarga, teman dan kenalan setelah merasakan layanan di Hospital Guido Valadares.

\section{Prosedur Pengumpulan Data}

Jenis Data 
Menurut sifatnya, penelitian ini menggunakan data kuantitatif dan data kualitatif.

a) Data kuantitatif merupakan data hasil serangkaian pengukuran yang dapat dinyatakan dalam angka-angka. Dalam penelitian ini yang termasuk data kuantitatif adalah imformasi tentang Bed Occupancy Rate (BOR), dan jumlah pasien rawat inap di Hospital Nasional Guido Valadares pada periode 2013 sampai dengan 2014

b) Data kualitatif merupakan data hasil dari serangkaian opservasi yang tidak dapat dinyatakan dalam bentuk angka-angka yaitu lokasi penelitian dan eveluasi pengalaman pasien yang didapatkan melalui kuisioner.

Menurut sumbernya, penelitian ini menggunakan data primer dan data sekunder.

a) Data primer merupakan data yang diperoleh langsung dari pasien melalui penyebaran kuesioner.

b) Data sekunder merupakan data yang diperoleh melalui dokumentasi dan reverensi yang berkaitan dengan penelitian ini yaitu imformasi tentang rumah sakit, literature dan jurnal penelitian terlebih dahulu yang berhubungan dengan permasalahan yang sedang dilalui.

\section{Populasi dan Sampel}

Populasi (population) mengaju pada keseluruhan kelompok, orang atau kejadian yang ingin diteliti (Sakaran, $2006: 121$ ), populasi dalam penelitian ini adalah seluruh pasien yang pernah dirawat inap di Hospital Nasional Guido Valadares pada periode 2013 - 2014

Sampel adalah bagian dari jumlah populasi yang dimiliki oleh populasi tersebut (Sakaran, 2006 : 122). Dalam penelitian ini, ukuran sampel ditentukan dengan mengaju pada persyaratan analisis bahwa ukuran sampel terbaik adalah lima sampai dengan sepuluh opservasi untuk setiap estimasi parameter (Solimun, 2006). Jumlah indikator dalam penelitian ini adalah 30 maka ukuran sampelnya berada pada rentang sampel 150-300 responden. Ukuran sampel dalam penelitian ini adalah adalah 150 responden 
Teknik sampling yang digunakan dalam penelitian ini adalah purposive sampling. Sugiyono (2010:68) menyatakan teknik purposive sampling adalah teknik penetuan sampel dengan pertimbangan tertentu. Adapun pertimbangan yang digunakan dalam penelitian ini adalah sebagai berikut :

1. Pasien rawat inap

2. Pasien yang dirawat inap minimal sekali dalam enam bulan terakhir

3. Pasien minimal berpendidikan SMA.

4. Dalam kasus terdapat pasien berpendidikan dibawah SMA atau masih dibawah umur, maka kuisioner dijawab dengan penduan oleh peneliti atau responden diwakili oleh orang tuanya / kerabatnya.

\section{Pengumpulan Data}

Dalam pengumpulan data yang dipergunakan adalah sebagai berikut :

a.Angket cara pengumpulan data dengan penyebaran kuisioner atau daftar pertayaan yang disusun secara sistimatis dengan beberapa pilihan jawaban yang mudah dipahami.

b.Dokumentasi data yang diperoleh dari dalam organisasi yang berkaitan dengan penelitian ini dengan cara mengutip atau menyalin data yang diperlukan.

\section{Instrumen Penelitian}

Data dikumpulkan dengan menggunakan kuesioner. Selanjutnya data inilah yang menjadi data utama untuk pengujian hipotesis. Kuesioner juga terdiri atas pertanyaan terbuka yang menanyakan lamanya pasien sudah menjalani rawat inap.

Sebelum melaksanakan penelitian dilakukan uji validitas dan reliabililas kuesioner melalui uji coba kuesioner untuk menghindari adanya pernyataan - pernyataan yang sulit dimengerti oleh responden. Uji validitas dan reliabilitas kuesioner melalui uji coba kuesioner untuk menghindari adanya pertanyaan-pertanyaan yang sulit dimengerti oleh responden. Uji validitas dan reliabilitas instrument dilaksanakan pada 30 pasien yang pernah dirawat di 
Hospital Nasional Gido Valadares Dili Timor Leste validitas dan reliabilitas instrument dilaksanakan pada 30 pasien yang pernah dirawat di Hospital Nasional Gido Valadares Dili Timor Leste

\section{Skala Pengukuran}

Skala pengukuran yanh digunakan dalam penelitian ini adalah skala Likert. Malhotra (2009:298) menyatakan skala Likert adalah skala yang digunakan secara luas yang meminta responden menandai derajat persetujuan atau ketidaksetujuan terhadap masing-masing serangkaian pertanyaan mengenai obyek stimulus.

\section{Uji validitas dan uji reliabilitas instrumen}

Sugiyono (2010:348) menyatakan hasil penelitian valid bila terdapat kesamaan antara data yang terkumpul dengan data sesungguhnya terjadi pada obyek yang diteliti. Hasil penelitian reliable bila terdapat kesamaan data dalam waktu yang berbeda. Jadi instrument yang valid dan reliable merupakan syarat untuk mendapatkan hasil penelitian yang valid dan reliabel. Uji validitas

Malhotra (2009:311) mendefinisikan uji validitas sebagai sejauh mana perbedaan skor skala yang diamati mencerminkan perbedaan sejati antara obyek atas karakteristik yang sedang diukur, ketimbangan kesalahan sistematik atau acak. Uji validitas dalam penelitian ini dilakukan dengan analisis factor konfirmatori.

\section{Metode Analisis Data}

\section{Analisis Deskriptif}

Analisis deskriptif digunakan untuk mendiskripsikan ketiga veriabel penelitian untuk itu analisis statistik yang digunakan adalah tabel frekuensi dari rata-rata skor yang diperoleh dari jawaban responden terhadap tiap indikator yang diperoleh dari responden terhadap tiap indikator yang diajukan dalam kuesioner dan digunakan untuk mengetahui karakteristik responden termasuk nilai frekwensinya dalam bentuk jumlah dan persentase serta menghitung 
nilai skore rata-rata untuk setiap indikator, dimensi maupun setiap variabel. Analisis ini dilakukan dengan mendeskripsikan data berdasarkan kecenderungan dari tanggapan responden terhadap item-item pertanyaan yang berkaitan dengan variabel penelitian ini.

\section{Analisis Jalur}

Teknik analisis data yang digunakan untuk menganalisis permasalahan dalam penelitian ini adalah analisis jalur. Analisis jalur dikembangkan sebagai metode untuk mempelajari pengaruh secara langsung dan tidak langsung dari variabel bebas terhadap variabel tergantung. Analisis ini merupakan salah satu pilihan dalam rangka mempelajari ketergantungan sejumlah variabel di dalam model. Analisis ini merupakan metode yang baik untuk menerangkan apabila terdapat seperangkat data yang lebih besar untuk dianalisis dan mencari hubungan kausal.

\section{HASIL DAN PEMBAHASAN}

\section{Karakteristik Responden}

Gambaran karaktistik responden penelitian dilihat dari jenis kelamin, umur, pendidikan, dan lama dirawat. Secara rinci data tersebut disajikan pada Tabel 1 berikut ini.

Tabel 1

Karakteristik Responden Penelitian

\begin{tabular}{|c|c|c|}
\hline Karakteristik & Jumlah (orang) & Proporsi $(\%)$ \\
\hline \multicolumn{3}{|l|}{ Jenis kelamin } \\
\hline Laki-laki & 77 & 51,3 \\
\hline Perempuan & 73 & 48,7 \\
\hline Total & 150 & 100,0 \\
\hline \multicolumn{3}{|l|}{ Umur } \\
\hline$<30$ & 44 & 29,5 \\
\hline $30-39$ & 47 & 31,3 \\
\hline $40-49$ & 25 & 16,7 \\
\hline $50-59$ & 19 & 12,7 \\
\hline$>60$ & 15 & 10,0 \\
\hline Total & 150 & 100,0 \\
\hline \multicolumn{3}{|l|}{ Pekerjaan } \\
\hline Karyawan swasta & 28 & 18,7 \\
\hline Pensiunan & 2 & 1,3 \\
\hline PNS & 27 & 18,0 \\
\hline Wiraswasta & 47 & 31,3 \\
\hline Tidak bekerja & 46 & 30,7 \\
\hline Total & 150 & 100,0 \\
\hline Pendidikan & & \\
\hline
\end{tabular}




\begin{tabular}{ccc}
\hline Tidak berpendidikan & 39 & 26,0 \\
SMA/sederajat & 83 & 55,3 \\
Akademi/diploma & 20 & 13,3 \\
Sarjana (Strata 1) & 8 & 5,3 \\
Total & $\mathbf{1 5 0}$ & $\mathbf{1 0 0 , 0}$ \\
\hline
\end{tabular}

Sumber : Hasil pengolaan data

\section{1). Uji Validitas dan Reliabilitas Instrumen Penelitian}

Dalam mengumpulkan data penelitian digunakan instrumen dalam bentuk kuesioner penelitian. Sebelum mengumpulkan data, terlebih dahulu diuji validitas dan reliabilitasnya. Dalam uji validitas instrumen digunakan validitas kriteria, yaitu dihitung berdasarkan korelasi antara skor tiap butir dengan skor total indikator. Instrumen dinyatakan valid jika memiliki korelasi positif dan lebih besar 0,30 seperti yang terlihat dalam Tabel 1

Berdasrkan hasil uji validitas instrumen, terbukti bahwa instrumen penelitian ini sudah valid karena seluruh butir pertanyaan dalam instrumen untuk semua variabel memiliki koefisien korerasi positip dengan nilai koefisien korelasi di atas 0,30 ( $r>0,30)$. Selengkapnya hasil uji validitas instrumen dapat dilihat pada Tabel 1

Untuk menguji reliabilitas instrumen digunakan reliabilitas konsistensi internal, yaitu dengan menghitung Alpha Cronbach. Instrumen penelitian dinyatakan reliabel jika memiliki nilai Alpha Cronbach lebih besar atau sama dengan 0,60 $(\alpha \geq 0,60)$. Berdasarkan hasil uji reliabilitas instrumen terbukti bahwa instrumen dapat dikatakan reliabel karena nillai Alpha Cronbach masing-masing variabel lebih besar dari 0,60. Hasil selengkapnya hasil uji reliabilitas instrumen dapat dilihat pada Tabel 2

Tabel 2

Tabel Hasil Uji Reabilitas

\begin{tabular}{ccc}
\hline No & Kontruk / Dimensi & Cronbach's Alpha \\
\hline 1 & Keandalan & 0,914 \\
2 & Daya Tanggap & 0,859 \\
3 & Jaminan & 0,840 \\
4 & Empati & 0,869 \\
5 & Bukti Fisik & 0,911 \\
6 & Kepuasan & 0,914 \\
7 & WOM & 0,859 \\
\hline
\end{tabular}




\section{2). Deskripsi Variabel Penelitian}

Dalam mendeskripsikan masing-masing variabel penelitian yaitu Kualitas Layanan (X), Kepuasan Pelanggan (Y1), dan WOM (Y2) didasarkan pada nilai rata-rata skor jawaban responden atas butir-butir pertanyaan dalam instrumen penelitian. Dalam menginterpretasi nilai rata-rata skor tiap variabel digunakan kriteria berikut:

Tabel 3

Rata-rata Skor Tiap Variabel

\begin{tabular}{cc}
\hline Rentangan nilai rata-rata skor & Interpretasi \\
\hline $1,00-1,80$ & sangat buruk \\
$1,81-2,61$ & Buruk \\
$2,62-3,42$ & cukup \\
$3,43-4,23$ & Baik \\
$4,24-5,00$ & sangat baik \\
\hline
\end{tabular}

Sumber : Hasil pengolaan data

Berdasarkan hasil analisis deskriptif, maka pada bagian berikut ini diuraikan secara berturut-turut variabel Kualitas layanan (X), Kepuasan pelanggan (Y1) dan WOM (Y2).

\section{(1) Deskripsi Variabel Kualiatas Layanan (X),}

Hasil analisis deskriptif variabel Kualitas Layanan (X) berupa proporsi jawaban responden pada alternatif jawaban untuk setiap butir pertanyaan, nilai skor rata-rata setiap butir dan nilai rata-rata skor setiap indikator serta nilai skor rata-rata keseluruhan untuk variabel.

Dengan memperhatikan informasi tersebut dapat diketahui bahwa kualitas layanan tergolong dipersepsikan baik oleh responden. Hal ini dilihat dari nilai skor rata-rata variabel kualitas layanan sebesar 3,93 dan mempunyai nilai rata-rata yang baik yang digambarkan seluruh indikator variabel kualitas layanan tabel ini adalah seluruh indikator demensi pada kualitas layanan yang terdiri dari keandalan, daya tanggap, jaminan dan empati serta bukti fisik dipresepsikan tinggi oleh pasien, begitu juga demensi yang lainnya seperti kepuasan dan WOM. 
Tabel 4

Deskripsi Variabel Kualitas Layanan (X)

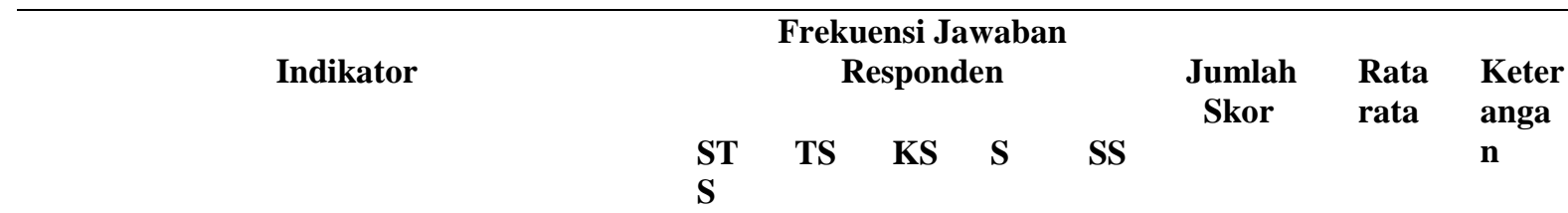

\section{Kualitas layanan $(\mathbf{X})$}

Petugas para medis (perawat atau bidan) mampu memberikan layanan sesuai yang dijanjikan manajemen Hospital Nasional

Petugas medis (dokter) terampil dalam mengobati pasien (X1.2)

Pengawai hospital Nasional Guido Valadares mampu memberikan layanan secara cepat sejak pertama kali pasien masuk rumah sakit (X1.3)

Pegawai hospital Nasional Guido Valadares memberikan layanan dengan tepat waktu sesuai dengan yang dijadwalkan (X1.4)

Pegawai hospital Nasional Guido Valadares memiliki data yang akurat tentang pasien (X2.1)

Para medis (dokter) memberikan imformasi sebelum imformasi diberikan (X2.2)

Pegawai hospital Nasional Guido Valadares memberikan layanan yang cepat kepada pasien (X2.3)

Pegawai hospital menunjukan kesedian membantu pasien (X2.4)

Pegawai hospital Guido Valadares selalu siap menanggapi permintaan pasien (X3.1)

Para medis (dokter) memberikan imformasi sebelum imformasi diberikan (X3.2)

Pegawai hospital Nasional Guido Valadares memberikan layanan yang cepat kepada pasien (X3.3)

Pegawai hospital menunjukan kesedian membantu pasien (X3.4)

Pegawai hospital Guido Valadares mampu menjawab pertayaan pasien dengan benar (X4.1)

Pegawai Hospital nasional Guido Valadaresmemberikan perhatian secara khusus kepada pasien (X4.2)

Para medis (dokter) mau meluangkan waktu untuk berdiskusi dengan pasien untuk menhilangkan ketakutan pasien (X4.3)

Pengawai Hospital Nasional Guido Valadares bersungguh-sungguh memperhatikan kepentingan pasien (X4.4) Pegawai Hospital Nasional Guido Valadares memehami kebutuhan spesifik pasien (X5.1)

\begin{tabular}{|c|c|c|c|c|c|c|c|}
\hline 0 & 8 & 28 & 83 & 31 & 587 & 3.91 & Baik \\
\hline 0 & 5 & 25 & 82 & 38 & 603 & 4.02 & Baik \\
\hline 0 & 6 & 31 & 63 & 50 & 607 & 4.05 & Baik \\
\hline 0 & 7 & 34 & 63 & 46 & 598 & 3.99 & Baik \\
\hline 0 & 7 & 36 & 66 & 41 & 591 & 3.94 & Baik \\
\hline 0 & 9 & 33 & 64 & 44 & 593 & 3.95 & Baik \\
\hline 0 & 6 & 31 & 63 & 50 & 608 & 4.05 & Baik \\
\hline 0 & 7 & 34 & 63 & 46 & 598 & 3.99 & Baik \\
\hline 0 & 7 & 36 & 66 & 41 & 591 & 3.94 & Baik \\
\hline 0 & 9 & 33 & 64 & 44 & 593 & 3.95 & Baik \\
\hline 0 & 9 & 43 & 53 & 45 & 584 & 3.89 & Baik \\
\hline 0 & 8 & 49 & 58 & 35 & 570 & 3.80 & Baik \\
\hline 1 & 5 & 39 & 70 & 35 & 583 & 3.89 & Baik \\
\hline 0 & 6 & 43 & 60 & 41 & 586 & 3.91 & Baik \\
\hline
\end{tabular}


ISSN : 2337-3067

E-Jurnal Ekonomi dan Bisnis Universitas Udayana 6.11 (2017): 3887-3916

\begin{tabular}{|c|c|c|c|c|c|c|c|c|}
\hline Waktu berkunjung pasien di Hospital Guido & & & & & & & & \\
\hline $\begin{array}{l}\text { Valadares tidak menganggu ketenangan } \\
\text { pasien (X5.2) }\end{array}$ & 0 & 7 & 43 & 63 & 37 & 580 & 3.87 & Baik \\
\hline $\begin{array}{l}\text { Hospital Nasional Guido Valadares memiliki } \\
\text { peralatan kedokteran yang moderen (X5.3) }\end{array}$ & 0 & 8 & 31 & 73 & 38 & 591 & 3.94 & Baik \\
\hline
\end{tabular}

\section{(2). Deskripsi Variabel Kepuasan Pasien (Y1)}

Tabel 5

Deskripsi Variabel Kepuasan Pasien (Y1)

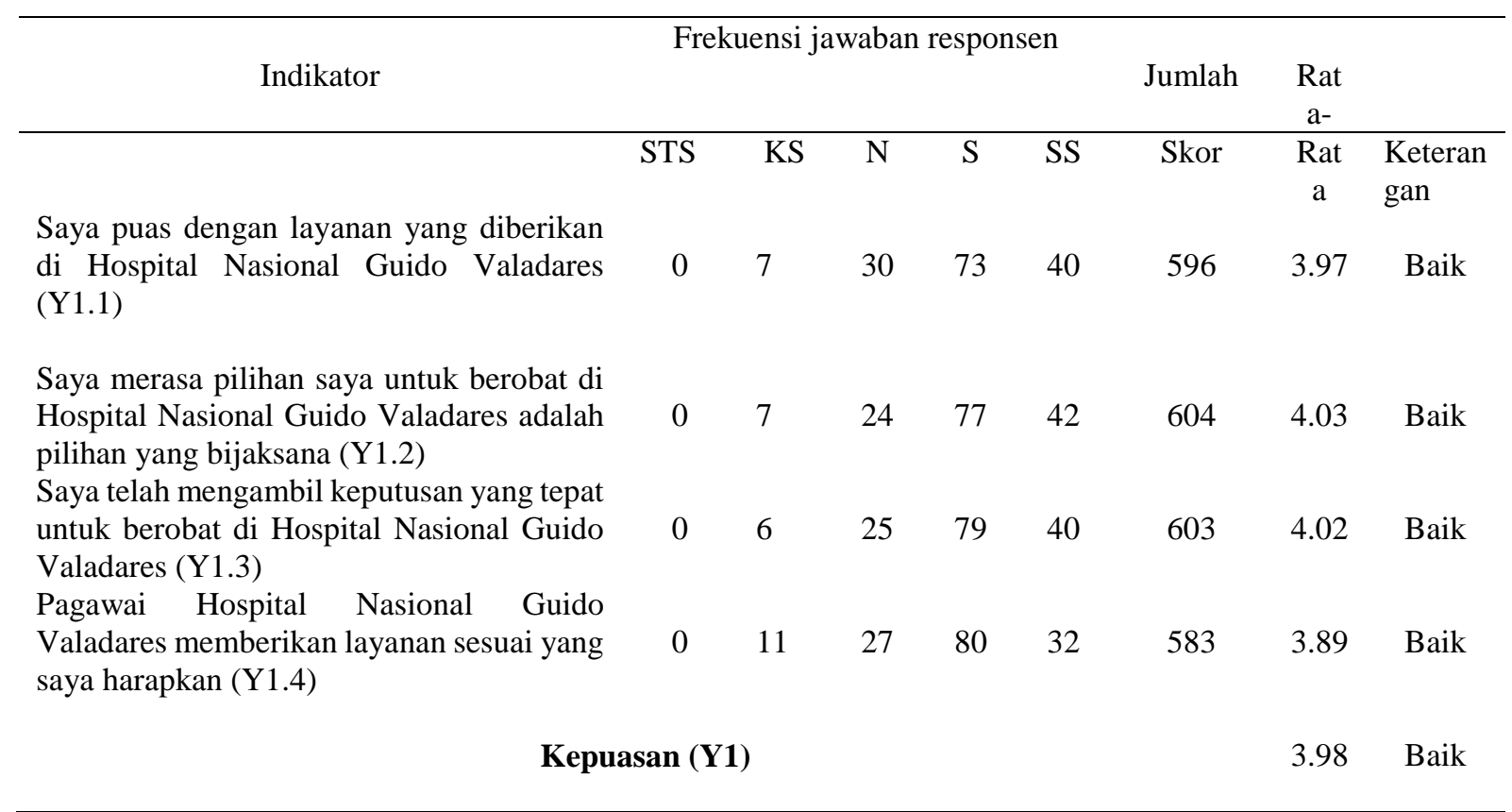

Sumber : Hasil pengolaan data

Tabel 6

Deskripsi Variabel WOM (Y2)

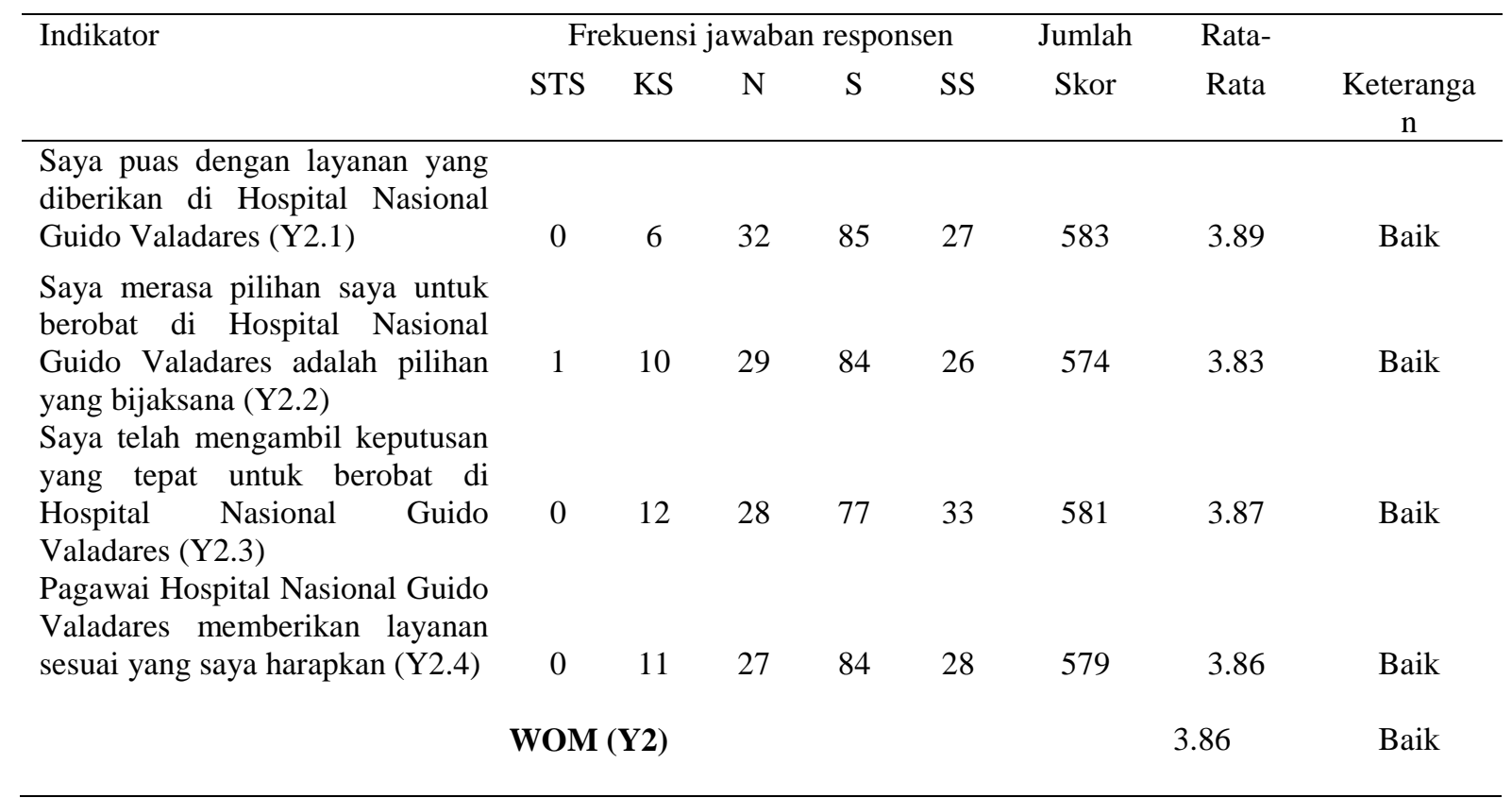


Sumber : Hasil pengolaan data

\section{(3). Analisis Faktor Konfirmatori}

Sebelum dilakukan analisis jalur, terlebih dahulu dilakukan analisis faktor konfirmatori untuk mengetahui bahwa indikator-indikator dari tiap variabel merupakan indikator yang valid dan reliabel mengukur variabel. Analisis faktor konfirmatori akan mengelompokkan indicatorindikator ke dalam beberapa faktor. Jika semua indikator merupakan indikator konstruk (variabel), maka dengan sendirinya akan mengelompok menjadi satu dengan faktor loading yang tinggi

Berdasarkan hasil analisis faktor konfirmatori untuk variabel Kualitas Layanan (X), Kepuasan Pelanggan (Y1) dan WOM (Y2) diketahui bahwa semua indikator dari tiap-tiap variabel mempunyai faktor loading dengan nilai di atas 0,60 . Rangkuman hasil analisis faktor konfirmatori disajikan pada Tabel 7 berikut ini

\section{Tabel 7}

Hasil Analisis Faktor Konfirmatori

\begin{tabular}{|c|c|c|c|c|c|}
\hline \multicolumn{2}{|c|}{ Kualiatas layanan $(\mathrm{X})$} & \multicolumn{2}{|c|}{ Kepuasan Pelanggan (Y1) } & \multicolumn{2}{|l|}{ WOM (Y2). } \\
\hline Indikator & $\begin{array}{l}\text { Faktor } \\
\text { Loading }\end{array}$ & Indikator & $\begin{array}{l}\text { Faktor } \\
\text { Loading }\end{array}$ & Indikator & $\begin{array}{l}\text { Faktor } \\
\text { Loading }\end{array}$ \\
\hline $\begin{array}{l}\text { Keandalan } \\
\text { (X1) }\end{array}$ & & $\begin{array}{l}\text { Saya puas dengan layanan } \\
\text { yang diberikan di Hospital }\end{array}$ & & $\begin{array}{l}\text { Saya puas dengan } \\
\text { layanan yang diberikan di }\end{array}$ & \\
\hline & 0,825 & $\begin{array}{l}\text { Nasional Guido Valadares } \\
\text { (Y1.1) }\end{array}$ & 0,803 & $\begin{array}{l}\text { Hospital Nasional Guido } \\
\text { Valadares (Y2.1) }\end{array}$ & 0,825 \\
\hline Daya & & $\begin{array}{l}\text { Saya merasa pilihan saya } \\
\text { untuk berobat di Hospital }\end{array}$ & & $\begin{array}{l}\text { Saya merasa pilihan saya } \\
\text { untuk berobat di Hospital }\end{array}$ & \\
\hline $\begin{array}{l}\text { tanggap } \\
(\mathrm{X} 1)\end{array}$ & 0,819 & $\begin{array}{l}\text { Nasional Guido Valadares } \\
\text { adalah pilihan yang } \\
\text { bijaksana (Y1.2) }\end{array}$ & 0,822 & $\begin{array}{l}\text { Nasional Guido } \\
\text { Valadares adalah pilihan } \\
\text { yang bijaksana (Y2.2) }\end{array}$ & 0,840 \\
\hline $\begin{array}{l}\text { Jaminan } \\
\text { (X3) }\end{array}$ & & $\begin{array}{l}\text { Saya telah mengambil } \\
\text { keputusan yang tepat untuk } \\
\text { berobat di Hospital }\end{array}$ & & $\begin{array}{l}\text { Saya telah mengambil } \\
\text { keputusan yang tepat } \\
\text { untuk berobat di Hospital }\end{array}$ & \\
\hline & 0,775 & $\begin{array}{l}\text { Nasional Guido Valadares } \\
\text { (Y1.3) }\end{array}$ & 0,882 & $\begin{array}{ll}\text { Nasional } & \text { Guido } \\
\text { Valadares (Y2.3) } & \end{array}$ & 0,895 \\
\hline Empati & & Pagawai Hospital Nasional & & Pagawai Hospital & \\
\hline (X4) & 0,741 & $\begin{array}{l}\text { Guido Valadares } \\
\text { memberikan layanan sesuai } \\
\text { yang saya harapkan (Y1.4) }\end{array}$ & 0,764 & $\begin{array}{l}\text { Nasional Guido } \\
\text { Valadares memberikan } \\
\text { layanan sesuai yang saya } \\
\text { harapkan (Y2.4) }\end{array}$ & 0,795 \\
\hline $\begin{array}{l}\text { Bukti fisik } \\
\text { X5 }\end{array}$ & 0,759 & & & & \\
\hline
\end{tabular}


Dengan memperhatikan Tabel 7 di atas, diketahui bahwa seluruh indikator tiap variabel memiliki loading factor di atas 0,60 sehingga dapat dikatakan bahwa indikator valid mengukur variabel.

\section{Hasil analisis jalur}

Dalam penelitian ini digunakan analisis jalur (path analysis) untuk menguji pengaruh Kualitas Layanan Terhadap kepuasan dan WOM. Berdasarkan hasil pengolahan data menggunakan program SPSS dapat diketahui hasil regresi untuk sub-struktur 1 dan substruktur 2, seperti disajikan pada Tabel 8 dan Tabel 9 berikut

Tabel 8

Hasil Regresi Struktur 1

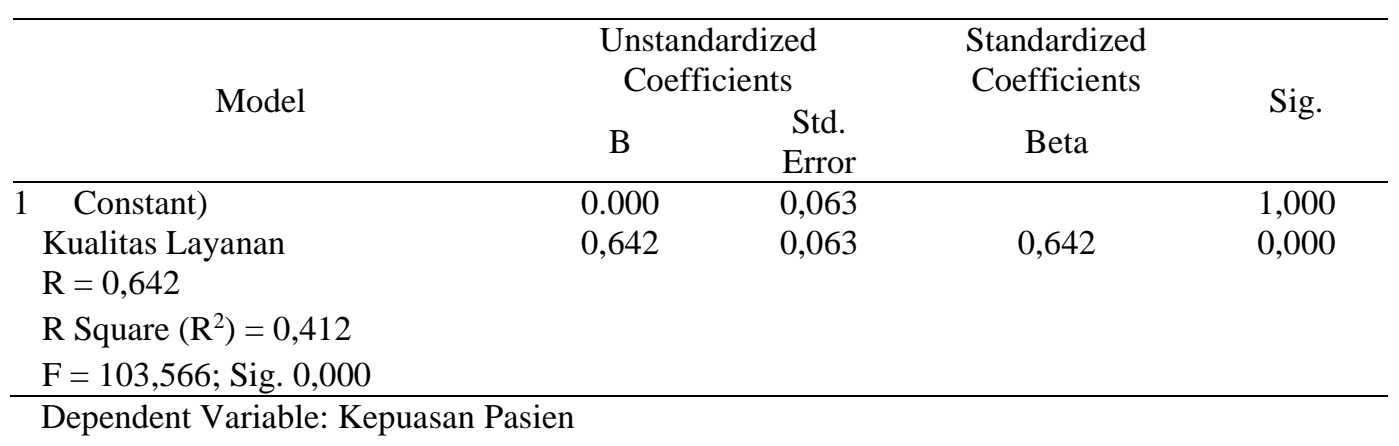

Tabel 9

Hasil Regresi Struktur 2

\begin{tabular}{|c|c|c|c|c|}
\hline \multirow{2}{*}{ Model } & \multicolumn{2}{|c|}{$\begin{array}{l}\text { Unstandardized } \\
\text { Coefficients }\end{array}$} & \multirow{2}{*}{$\begin{array}{c}\text { Standardized } \\
\text { Coefficients } \\
\text { Beta }\end{array}$} & \multirow{2}{*}{ Sig } \\
\hline & $\mathrm{B}$ & $\begin{array}{l}\text { Std. } \\
\text { Error }\end{array}$ & & \\
\hline $1 \quad$ Constant) & 0.000 & 0,055 & & 1,000 \\
\hline Kualitas layanan & 0,535 & 0,072 & 0,535 & 0,000 \\
\hline Kepuasan Pelanggan & 0,273 & 0,072 & 0,273 & 0,000 \\
\hline \multicolumn{5}{|l|}{$\mathrm{R}=0,741$} \\
\hline \multicolumn{5}{|l|}{$\mathrm{R}$ Square $\left(\mathrm{R}^{2}\right)=0,549$} \\
\hline \multicolumn{5}{|l|}{$\mathrm{F}=84,971 ;$ Sig. 0,000} \\
\hline Sumber : Hasil pengolaan & & & & \\
\hline
\end{tabular}

\section{Goodness of Fit Model}


Dalam analisis jalur model dikatakan fit jika didukung oleh data empirik. Uji goodness of fit dapat dilihat pada hasil analisis jalur pada Regresi sub struktur 1 dan sub struktur 2 seperti disajikan pada Tabel 8 dan Tabel 9 di atas. Goodness of Fit model struktural pada analisis jalur berupa nilai Koefisien Determinasi Total $\left(R_{M}^{2}\right)$. Berdasarkan Hasil regresi sub struktur 1 dan sub struktur 2 diketahui nilai $\mathrm{R}^{2}$ masing-masing variabel endogen, yaitu: Kepuasan Pasien (Y1) diperoleh $\mathrm{R}^{2}$ sebesar 0,412, dan untuk variabel WOM (Y2) diperoleh $\mathrm{R}^{2}$ sebesar 0,549. Selanjutnya maka dapat dihitung nilai predictive-relevance, dengan rumus sebagai berikut.

$$
\begin{aligned}
& R_{M}^{2}=1-\left(1-\mathrm{R}_{1}^{2}\right)\left(1-\mathrm{R}_{2}^{2}\right) \\
& R_{M}^{2}=1-(1-0,412)(1-0,549)=1-(0,588)(0,451)=1-0,265188 \\
& R^{2}{ }_{M}=0,734812
\end{aligned}
$$

Diketahui nilai $R_{M}^{2}=0,734812$ atau 73,48 persen, menunjukan bahwa keragaman data mampu menjelaskan model sebesar 73,48 persen. Hasil ini dapat diartikan bahwa WOM dijelaskan oleh Kualitas layanan dan kepuasan pelanggan sebesar 73,48 persen dan sisanya 22,52 persen dijelaskan oleh variabel lain yang tidak dibahas dalam penelitian ini. Dengan demikian model dapat dikatakan baik sehingga layak untuk memberikan penjelasan dan pengujian hipotesis.

\section{Hasil Pengujian Hipotesis}

Hipotesis diuji dengan t-test pada masing-masing jalur pengaruh langsung secara parsial. Hasil analisis secara ringkas analisis jalur dapat dilihat pada Tabel 5.11 menyajikan hasil pengujian hipotesis pengaruh langsung

Tabel 10

Hasil Pengujian Hipotesis

\begin{tabular}{lccc}
\hline Hubungan antar Variabel & $\begin{array}{l}\text { Koefisien Jalur } \\
\text { (Standardize) }\end{array}$ & p-value & Keterangan \\
\hline $\begin{array}{l}\text { Kualitas layanan }(\mathrm{X}) \rightarrow \text { Kepuasan } \\
\text { pelanggan (Y1) }\end{array}$ & 0,642 & 0,000 & Signifikan \\
$\begin{array}{l}\text { Kualitas layanan }(\mathrm{X}) \rightarrow \text { WOM } \\
(\mathrm{Y} 2)\end{array}$ & 0,535 & 0,000 & Signifikan \\
\hline
\end{tabular}




\begin{tabular}{llll}
\hline $\begin{array}{l}\text { Kepuasan Pelanggan (Y1) } \rightarrow \\
\text { WOM (Y2) }\end{array}$ & 0,273 & 0,000 & Signifikan \\
Sumber : Hasil pengolaan data & &
\end{tabular}

Hasil pengujian hipotesis jalur-jalur pengaruh langsung juga dapat dilihat pada gambar diagram jalur sebagai berikut

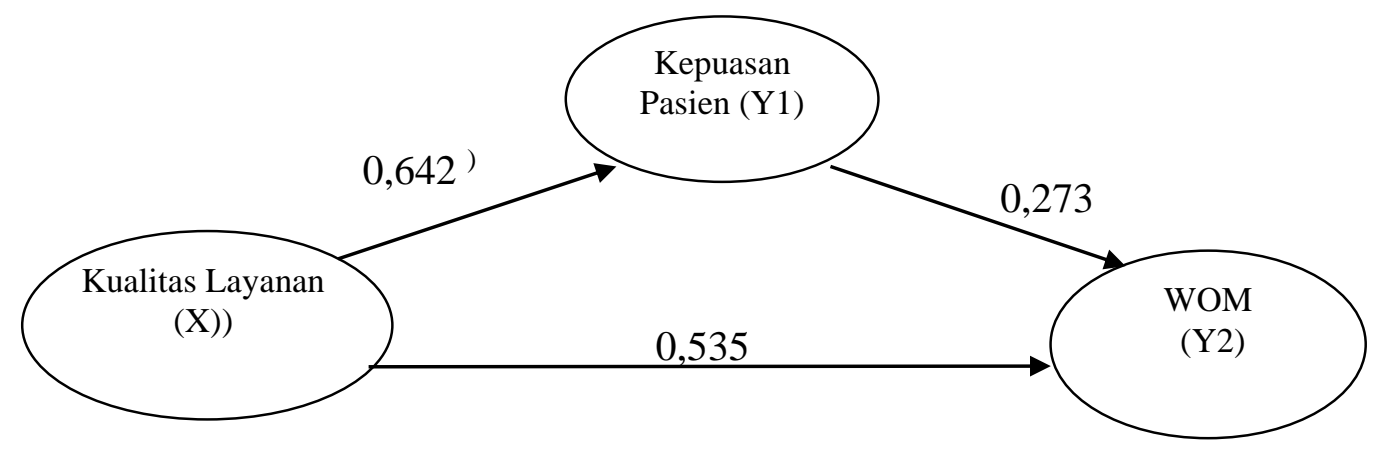

Gambar 2

Diagram Jalur Pengaruh Langsung

Berdasarkan hasil pengujian hipotesis secara statistik pada Tabel 5.11 dan Gambar 1 maka didapatkan sebagai berikut.

Kualitas Layanan (X) berpengaruh signifikan terhadap Kepuasan pelanggan(Y1). Hasil analisis diperoleh koefisien jalur bertanda positip sebesar 0,642 dengan $\mathrm{p}=0,000$ lebih kecil dari $\alpha(0,005)$. Hasil tersebut menunjukan bahwa kualitas layanan berpengaruh positif dan signifikan terhadap kepuasan pelanggan. Dengan demikian hipotesis terbukti mengetahui koefisien jalur bertanda positif, maka dapat diartikan bahwa semakin baik kualitas layanan (X1) maka kepuasan pelanggan (Y1) juga semakin baik atau semakin tinggi.

Kualitas layanan (X) berpengaruh signifikan terhadap WOM (Y2). Hasil analisis diperoleh koefisien jalur sebesar 0,535 dengan $\mathrm{p}=0,000$ lebih kecil dari $\alpha(0,005)$, sehingga dikatakan signifikan. Dengan demikian hipotesis terbukti. Mengingat koefisien jalur bertanda positif, 
Roslina Lali Wuda, Ni Wayan Sri Suprapti., Pengaruh Kualitas Layanan Terhadap Kepuasan ....

dapat diartikan bahwa semakin baik Kualitas Layanan (X) maka WOM (Y2) juga semakin baik.

Kepuasan palanggan (Y1) berpengaruh signifikan terhadap WOM (Y2). Hasil analisis diperoleh koefisien jalur sebesar 0,273 dengan $p=0,000$, lebih kecil dari $\alpha(0,005)$, yang berarti signifikan. Dengan mengatahui koefisien jalur bertanda positif, dapat diartikan bahwa semakin baik atau semakin puas pelanggan maka WOM juga akan semakin baik.

\section{PEMBAHASAAN}

Dari hasil-hasil pengolahan data tersebut di atas, dapat disimpulkan bahwa hasil-hasil penelitian antara lain: (1) pengaruh secara langsung kualitas layanan terhadap kepuasan para pasien (2) pengaruh secara langsung antara kualitas layanan dan WOM (3) pengaruh langsung kapuasan pasien terhadap $W O M$

\section{Pengaruh Langsung kualitas layanan terhadap kepuasan Para Pasien}

Hasil pengujian olah data pada Tabel 10 menunjukan bahwa kualitas layanan berpengaruh positif dan signifikan terhadap kepuasan para pasien dengan nilai 0,642 . Hasil penelitian ini dapat diartikan bahwa semakin baik kualitas layan maka kepuasan pasien akan semakin tinggi. Hasil penelitian ini mendukung penelitian yang telah dikemukaka oleh Gronroos dalam ( Edi Rusandi 2004:11 dan 19) bahwa kualitas adalah apa yang konsumen katakan. Dalam hal ini mengandung makna bahwa kualitas hendaknya dilihat dari sudut pandang konsumen, konsumenlah menentukan nilai kualitas. Utama (2003) menyatakan kepuasan pasien dipengaruhi oleh dimensi kualitas layanan yang dirasakan pasien yaitu tentang keandalan, daya tanggap, jaminan, empati, dan bukti fisik.

\section{Pengaruh Secara Langsung Kualitas Layanan Terhadap WOM}

Dalam pengujian hipotesis menunjukan bahwa kualitas layanan berpengaruh positif dan signifikan terhadap WOM pada Pasien Rawat Inap Hospital Nasional Guido Valadaresdengan nilai probabilitas 0,000 dan nilai koefisien 0,535 . Dari hasil penelitian ini diartikan bahwa 
semakin tinggi kualitas layanan semakin tinggi keinginan pesien untuk melakukan komunikasi WOM positif dengan merekomendasi Hospital Nasional Guido Valadares Dili Timor Leste kepada keluarga, kerabat, dan kenalannya. Hasil penelitian ini mendukung hasil penelitian yang dilakukan oleh TJiptono (2008:90) WOM biasanya bersifat kredibel dan efektif kerena yang menyampaikannya adalah orang-orang yang dapat dipercayai pelanggan, seperti para ahli, teman, tetangga, keluarga, rekan kerja dan publisitas media massa.

Penelitian yang dilakukan oleh Sutomo (2009) menemukan bahwa kualitas layanan mempunyai pengaruh positif dan signifikan terhadap kepuasan pelanggan. Suprapti (2010:248) menyatakan bila pemasar ingin meningkatkan komunikasi getok tular atau WOM yang positif tentang produknya, mereka harus paham tentang : Proses komunikasi getok tular yaitu komuniksi yang mengalir dari para pemimpin opini kepada pengikutnya. Hal yang paling penting dari aliran komunikasi ini adalah apakah imformasi yang disampaikan bersifat negatif atau positif.

\section{Pengaruh Langsung Kapuasan Pasien Terhadap WOM}

Dari hasil pengujian hipotesis menunjukan bahwa kepuasan berpengaruh positif dan signifikan terhadap WOM pada Pasien Rawat Inap Hospital Nasional Guido Valadares dengan nilai probabilitas 0.000 dan nilai koefisien 0.273 . penelitian ini dapat diartikan bahwa semakin tinggi kepuasan yang dirasakan oleh pasien, maka semakin tinggi keinginan yang dilakukan dalm komunikasi WOM yang positif kepada keluarga, kerabat dan kenalannya.Berdasarkan penelitian ini mendukung hasil penelitian yang dilakukan oleh Assail (2004:468) menyatakan komunikasi WOM negative mempunyai pengaruh yang lebih besar dari pada WOM positif dan juga yang ditemukan oleh Brouwn et al (202005) yang menyatakan konsumen yang merasa tingkat kepuasan yang maksimal akan memiliki kecendrungan untuk melakukan WOM positif.

\section{Implikasi Penelitian}


Berdasarkan penelitian ini diharapkan dapat memberikan masukan kepada manajemen dan karyawan hospital Nasional Guido Valadares sebagai berikut :

a. Implikasi Teoritis berdasarkan pembahasan mengenai kualitas layanan dalam meningkatkan kepuasan dan WOM pada pasien rawat inap Hospital Nasional Guido Valadares. pihak manajemen hendaknya tetap memperhatikan kualitas layanan untuk ditingkatkan di masa yang akan datang karena harapan pasien secara umum akan terus meningkat seiring dengan perubahan lingkungan. Peningkatan harapan ini biasanya akan selalu dibandingkan dengan kinerja tentang kualitas layanan yang diterima. Perbaikan yang perlu dilakukan ditujukan bagi indiator-indikator yang memperoleh skor penilaian paling rendah dan harus mendorong para medis (dokter dan perawat) agar selalu berupaya membangkitkan rasa percaya diri pasien atau menanggulangi rasa takut sebelum tindakan diberikan serta selalu berupaya memahami kebutuhan dan keinginan pasien dengan meningkatkan komunikasi dengan pasien dan keluarganya.

b. Implikasi praktis

Penilaian pasien terhadap 30 indikator penilitian ini dapat dipakai sebagai imformasi, indikator angka manakah yang perlu untuk mendapatkan perhatian kusus dan harus segera dialkukan perbaikan. Hasil penelitian menunjukan bahwa semua indikator dipersepsikan tinggi oleh pasien. Dan selanjutnya dapat dihitung dengan nilai $R_{M}^{2}=0,734812$ atau 73,48 persen, menunjukan bahwa keragaman data mampu menjelaskan model sebesar 73,48 persen. Hasil ini dapat diartikan bahwa WOM dijelaskan oleh Kualitas layanan dan kepuasan pelanggan sebesar 73,48 persen dan sisanya 22,52 persen dijelaskan oleh variabel lain yang tidak dibahas dalam penelitian ini. Dengan demikian model dapat dikatakan baik sehingga layak untuk memberikan penjelasan dan pengujian hipotesis. Hal ini menunjukan bahwa manajemen Hospital Nasional Guido Valadares Dili Timor Leste harus berusaha meningkatkan kemampuan dari pengawai hospital Nasional Guido Valadaresdalam 
memenuhi kebutuhan spesifik dari masing-masing pasien. Hal ini bisa dilakukan dengan memberikan pelatihan-pelatihan kepada pengawai Hospital Nasional Guido Valadares Dili Timor Leste.

Kualitas layanan yang diterima oleh pasien rawat inap Hospital Nasional Guido Valadares Dili Timor Leste tidak hanya mempengaruhi kepuasan, pasien rawat inap akan bersedia dalam melakukan komunikasi WOM positif kepada keluarga, teman dan kenalannya. Oleh sebab itu manajemen Hospital Nasional Guido Valdares Dili Timor Leste harus memperbaiki kualitas layanan yang diberikan kepada para pasien yang berkesinambungan dengan selalu memperhatikan kualitas dari sumer daya manusia, peralatan kedokteran dan fasilitas penunjang lainnya serta membaut program-program layan yang bisa memberikan nilai lebih kepada pasien.

Kepuasan pelanggan berpengaruh terhadap WOM, pasien, maka dari itu manajemen Hospital Nasional Guido Valadares Dili Timor Leste harus terus berusaha meningkatkan kepuasan pelanggan. Ada beberapa cara yang bisa dilakukan yaitu dengan menyediakan kotak saran atau dengan menyebarkan kuisioner kepada pasien secara berkala.

\section{Keterbatasan Penelitian}

Penelitian ini hanya dilakukan pada Hospital Nasional Guido Valadares Dili Timor leste. Sehingga hasil penelitian ini hanya berlaku bagi pasien yang datang dirumah sakit tersebut. Hasil ini tidak bisa di generalisasi untuk pasien di rumah sakit lainnya.

\section{SIMPULAN DAN SARAN}

Berdasarkan hasil analisis dapat disimpulan sebagai berikut:

Kualitas layanan yang diberikan di Hospital Nasional Guido Valadares Dili Timor Leste berpengaruh positif dan singnifikan terhadap kepuasan pasien. Hal ini berarti semakin baik layanan yang diberikan kepada pasien, maka pasien akan semakin puas dengan layanan. 
Kualitas layanan berpengaruh positif dan singnifikan terhadap WOM pada pasien rawat inap Hospital Nasional Guido Valadares Dili Timor Leste yang berarti bahwa semakin baik kualitas layanan yang diberikan kepeda pasien maka akan meningkatkan kesedihan pasien untuk menyampaikan WOM positif kepada keluarga, teman dan kenalannya.

Kepuasan terhadap layanan yang diterima barpegaruh positif dan singnifikan terhadap WOM pada pasien rawat inap di Hospital Nasional Guido Valadares Dili Timor -Leste yang berarti semakin puas pasien dengan layanan yang dirasakan ,maka kesedian pasien untuk menyampaikan WOM positif akan semakin meningkat.

Berdasarkan hasil penelitian, pembahasandan kesimpulan yang telah disampaikan sebelumnya, maka dapat disarankan bagi manajemen rumah saki sebagai berikut:

Berdasarkan hasil penelitian, diperoleh bahwa seluruh indikator kualitas layanan dinilai baik oleh pasien rawat inap. Namun demikian, pihak manajemen hendaknya tetap memperhatikan kualitas layanan untuk ditingkatkan di masa yang akan datang karena harapan pasien secara umum akan terus meningkat seiring dengan perubahan lingkungan. Peningkatan harapan ini biasanya akan selalu dibandingkan dengan kinerja tentang kualitas layanan yang diterima. Perbaikan yang perlu dilakukan ditujukan bagi indiator-indikator yang memperoleh skor penilaian paling rendah seperti:

Variabel kualitas layanan pada indikator (X1.3) pengawai Hospial Nasional Guido Valadares tidak mampu memberikan layanan secara cepat sejak pertama kali pasien masuk rumah sakit Terlihat juga pada variabel kepuasan pasien dalam indikator (Y1.4) bahwa pengawai Hospital Nasional Guido Valedares tidsk msmpu memberikan layanan yang sesuai dengan keinginan para pasien. Pada variabel WOM dalam indikator (Y2.2) apabila ada yang menanyakan pendapat saya tentang rumah sakit yang baik maka saya tidak akan menyarankan supaya tidak memilih rumah sakit ini. Saran atas permasalahan pihak manajamen rumah sakit harus mampu mendorong para medis (dokter dan perawat) agar selalu berupaya membangkitkan rasa percaya 
diri pasien atau menanggulangi rasa takut sebelum tindakan diberikan serta selalu berupaya memahami kebutuhan dan keinginan pasien dengan meningkatkan komunikasi dengan pasien dan keluarganya. Rumah sakit harus mampu dalam mempertahankan agar para pasien bisa merasa puas dalam memilih Hospital Nasional Guido Valadares sebagai suatu pilihan yang bijaksana. Pihak manajamen rumah sakit harus mampu mendorong para medis (dokter dan perawat) agar selalu berupaya membangkitkan rasa percaya diri pasien atau menanggulangi rasa takut sebelum tindakan diberikan serta selalu berupaya memahami kebutuhan dan keinginan pasien dengan meningkatkan komunikasi dengan pasien dan keluarganya. Manajemen rumah sakit harus mampu dalam mempertahankan agar para pasien bisa merasa puas dalam memilih Hospital Nasional Guido Valadares sebagai suatu pilihan yang bijaksana.

\section{REFERENSI}

Chaniotakis, I.E., Lymperopoulos. C. 2009. Service Quality Effect on Stisfaction and Word of Mouth in the Health Care Industry. Journal of Managing Service Quality, Vol. 19. No. 2. Pp, 229-242.

Rusandi E. 2007. Pengaruh Kualitas Layanan terhadap loyalitas di Omedata Electronocs Bandung

Gunawan K, . Djati SP 2011 kualitas layanan dan loyalitas pasien. Jurnal Manajemen Dan Kewirausahaan, Vol.13. No 1. Pp. 33-34

Hartono, B. 2010. Manajemen Pemasaran Untuk Rumah Sakit. Edisi Pertama. Jakarta: Rineka Cipta.

Olorunniwo, F., Hsu, M.K., Udo, G.J. 2006. Service Quality, Costumer Satisfaction, and Behavioral Intentions in the Service Factory. The Journal of Service Marketing, Vol. 20. No. 1. pp. 59-72.

Kotler P., dan Keller K.L., 2009. Manajemen Pemasaran, Jilid 2, Edisi 13, Jakarta : PT. Gelora Aksara Pratama

Lovelock, C., Wirtz, J. 2007. Services Marketing : People, Technology, Strategy. Sixth Editin. Singapore : Prentice Hall.

Malhotra, N.K. 2009. Riset Pemasaran Pendekatan Terapan (Soleh Rusyadi Maryam, Penterjemah). Edisi Keempat. Jakarta ; PT Indeks.

Parasuraman, A., Zeithaml, V.A., Berry, LL. 1988, Servqual : A Multiple-Item Scale for Measuring Costumer Perception of Service Quality. Journal of Marketing, Vol. 4. pp. $12-40$.

Praswati, A.N. 2009. Analisa Faktor-Faktor Yang Mempegaruhi Komunikasi Word of Mouth Terhadap Minat Guna Jasa Ulang, Tesis, Program Pascasarjana Universitas Doponogoro tidak dipublikasikan.

Sekaran, U. 2006. Metodelogi Peneltian Untuk Bisnis. Edisi Kedua Jakarta : Salemba Empat.

Shabbir, S,. Kaufmann, H.R.,Shahzad, M,2010. Service Quality, word of mauth and trust: Drivers to achieve patient satisfaction. Scientific Researcch and Essays Vol.5 No.17 pp 2457-2462 
Solimun. 2005. Structural Equation Modeling. Surabaya : Universitas Katolik Widya Mandala.

Sugiyono. 2010. Statistika Untuk Penelitian. Edisi Ketujuh Belas. Bandung: Penerbit Alfabeta. Suprati, N.W.S. 2010. Perilaku Konsumen Pemahaman Dasar dan Aplikasinya dalam Strategi Pemasaran, Udayana University Press.

Supriyanto, S., Ernawaty. 2010. Pemasaran Industri Jasa Kesehatan, Yogyakarta. CV. Andi Offset.

Sutomo, A. 2009. Analisis Faktor-Faktor yang Mempengaruhi Kepuasan Pasien dan Pengaruhnya Terhadap Minat Mereferensikan Pelayanan Rawat Jalan Pada RS ParuParu Sukosari Husada Sukoharjo, Tesis, Program Pascasarjana Universitas Diponogoro tidak dipublikasikan.

Tjiptono, F. 2008. Service Management Mewujudkan Layanan Prima, Jakarta: CV. Andi Offset

Utama,A 2003 Analisis Pengaruh Presepsi Kualitas Pelayanan Terhadap Kepuasan Pelanggan Rumah Sakit Umum Cakra Husada Klaten. Opsi, Vol 1 No 2 pp 96-110 Wayuningsih., Nurdin, D. 2009. The Effect of Costumer Satisfication on Behavior Intentions. Jurnal Manajemen Bisnis. Vol 3. No. 1. pp. 1-16. 